\title{
Gabrio Piola and Balance Equations
}

\author{
by Giuseppe Ruta
}

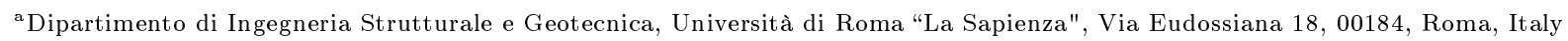

\section{Introduction}

The origin of modern continuum mechanics dates back to Cauchy [1]-[8] and Poisson [9, 10], who investigated linear elastic solids and fluids subject to infinitesimal displacements. This is stated in the well known monographs on history of mechanics by Todhunter and Pearson [11], Dugas [12], Timoshenko [13], Benvenuto [14] . We find some more hints on the origins of the theory of elasticity also in the recent contributions by Capecchi et al. $[15,16,17]$. Cauchy and Poisson imagined natural bodies as constituted by very small particles of matter interacting by central forces. However, they derived continuum field equations by suitable analytical tricks, and eventually Cauchy adopted only continuous functions to describe the regions of ambient space filled by a huge number of particles very close to each other. Since then, continuum mechanics has influenced all basic studies on theoretical and applied mechanics, enlarging both its scopes and range of applications: electro-magnetism and heat/work are only two of them. Examples of continuum mechanics in these fields are provided by the pioneering works by Green [18] and Thomson [19, 20]; comprehensive expositions are the well known ones by Truesdell and Toupin [21] and Truesdell and Noll [22]; a more recent handbook is that by Gurtin et al. [23].

Structured continua, originated by the Cosserats [24, 25], represent another branch of continuum models and their study has lead to an established theory, see Capriz [26] for instance. Indeed, continua with (micro-)structure are optimal models for many objects in multiple fields of application: they may describe non-standard beams [27, 28], damaged structural elements [29], masonry [30, 31, 32], plasticity [33]. In addition, they may provide suitable frameworks for multi-field physics, such as piezoelectricity or the mechanics of mixtures or porous media: the various physical quantities entering the phenomena are seen simply as additional degrees of freedom in a generalized lagrangean system.

Gabrio Piola (1794-1850) stood out among the Italian scholars in mechanics in the first half of 1800, though he was never in charge of a university chair. In a series of papers, published in Italian in some journals of almost no diffusion outside Italy [34]-[38], he was perhaps the first to present: a) a clear separation among kinematics, expressed by suitable constraint equations, and balance, expressed by Lagrange's virtual work [39], according to which inner actions are simply mechanical duals of suitable constraint equations; b) a clear statement that physical considerations on the constitution of inner actions lie beyond the position of kinematics and balance and are independent of them; c) an imaginary ideal state for any body, made up of a perfectly regular array of molecules, free of any stress; d) an imaginary intermediate configuration between the natural and the actual ones, so that constraint equations exist; and e) the possibility to obtain balance equations by considering a change in observer for the present configuration. These key points in Piola's principles of mechanics are put into evidence by Hellinger [41], and described with some depth in other studies on Piola's works [40, 47]. The aim of this work is, however, to stress the above said points, that seem quite original and basic for a more general theory of continua with respect to that by Cauchy, Poisson and their successors (among them Lamé [42] and Saint-Venant [43, 44]), well before the Cosserats', and with a very modern spirit.

Piola's work is in general not well known in the international scientific mechanics community, because of his nationalistic attitude of writing in Italian and to practice mechanics as an amateur. We also cannot directly ascribe any Italian academic school to him, yet his influence is undoubtable on Francesco Brioschi (1824-1897), who taught in Pavia and founded the polytechnical school in Milan, and who passed this influence for sure to his doctorate students Eugenio Beltrami (1835-1899), Felice Casorati (1835-1890), and Luigi Cremona (1830-1903), some of the founders of the Italian school of mathematical physics. On the other hand, the theory of elasticity and of structures, that in France was closely linked to the scholars in the Grandes Écoles, in Italy seem to take origin in Turin after Luigi Federico Menabrea (1809-1896), influenced by Lagrange's inheritance, and his indirect pupils Carlo Alberto Castigliano (1847-1884) and Valentino Cerruti (1850-1909) [45, 46]: they perfected the idea of minimum work, and applied theorems of minimum work in the study and design of engineering structures, especially trusses and frames.

In this contribution, I will shortly sketch some instances linked to Piola's derivation of mechanical balance equations as presented in his first papers. On the other hand, I will spend more time to analyze in some depth Piola's lucid self-criticism and self-corrections, leading him to expose, in his last two papers, and especially in his posthumous one, a well formulated, and still up-to-date, continuum mechanics theory. 


\section{Condition equations and balance}

Piola's first work on mechanics considers the application of Lagrange's analytical mechanics to many problems [34]. Apart from this testimonial of affection to his master, all of Piola's following works are devoted to extend Lagrange's ideas to continuum mechanics:

Mechanics of bodies extended according to the three dimensions, solids and fluids of any kind, has recently been promoted through the investigations of two famous French geometers, Poisson and Cauchy, who dealt with very difficult problems not touched before. The latter in his Exercises of Mathematics gave some double solutions, that is, by the hypothesis of continuous matter, and by the hypothesis of matter considered as an aggregate of distinct molecules at very small distances: on the other hand, the former, believing that supposing the matter continuous does not give reason of natural phenomena, kept preference on the other hypothesis, wishing to rebuild Mechanics from the ground by it. Before the above said geometers, Lagrange had dealt with various problems relative to the mechanics of solids and fluids, creating a new science for this as well as for all other questions of equilibrium and motion: I mean to speak of the Analytical Mechanics, a work still praised nowadays, and which is called the real philosophical mechanics but in fact is considered a bit more than a piece of erudition. Since I have had in my first youth a particular occasion to make a profound study of this work, I made myself so high an idea of the generality and power of its methods, that I came to believe them, in comparison with the methods used before, a prodigy of invention not less than differential and integral calculus with respect to Cartesian analysis: and I thought and wrote to be impossible henceforth any investigation on rational mechanics that were not performed in this way. Having afterwards examined the recent memoirs, and having remarked how in them (but for some rare occasion) the analysis that had struck me so much is not used, I thought that I had gone wrong, that is, that the new mechanical questions could not be subjected to the methods of Analytical Mechanics. I tried, however, to convince myself of this by means of an experiment: and then it was a great surprise of mine to realize that in this way they fit into it very well, and get much clear: a going in the proof that satisfies one's spirit: confirmation in some places, changes in other: and, which is more, new theorems in addition. This is the reason that pushed me to publish a series of Memoirs on the quoted subject, to try to drive some readers to my belief: but before the proofs of fact I thought of posing some general meditations aimed at showing, at least for what is in my ability, the deep of the knowledge which is found in the greatest work of the sublime Italian Geometer. ${ }^{1}$

Thus, Piola's mechanics was a branch of pure knowledge, i.e., of philosophy, following the 'natural philosophers' of classical Greece, Newton (remind the latter's distinction between 'rational' and 'practical' mechanics in the Principia), and Lagrange. Piola's mechanics is a procedure of logical thinking by rigorous deductions (hence the adjective 'rational' juxtaposed to the noun 'mechanics'), the principles of which shall be undoubtable because of empiric evidence. Piola did not despise applications-simply, he was more interested in the logical way to frame natural phenomena into a rigorous system of deductions:

I would not like a physical mechanics ${ }^{2}$ the first equations of which, meditated upon rather uncertain hypotheses, would obtain but a weak confirmation, going from the general to the particular, by some corrispondence with observed phenomena. Good philosophy, made expert by the aberrations of many of those thinkers that built systems about natural things, deduces from the multiplicity and contradiction themselves of their opinions, that the way of making philosophy is not right, that has a support only in its end, and not a sufficient one in its beginning. If these considerations are right, anybody sees how interesting is to recover study and practice upon A. M., which is the only one to establish fundamental equations needing a few dates the truth of which is undebatable. ${ }^{3}$

Piola's rebuilding of mechanics on undoubtable facts is based on a personal definition of inner actions. Cauchy and Poisson (and Navier before them), independent of the corpuscular/continuous nature of matter, derived inner actions by postulating that they derive from Newtonian central forces: thus, the particles of a body-universe interact like the particles of the world-universe, and 'pressure' (nowadays

\footnotetext{
${ }^{1}$ La meccanica de' corpi estesi secondo le tre dimensioni, solidi e fluidi di ogni sorta è stata recentemente promossa mediante le ricerche di due insigni geometri francesi, Poisson e Cauchy, i quali trattarono problemi assai difficili per l'addietro non toccati. Il secondo di essi ne' suoi Esercizi di Matematica diede alcune soluzioni in doppio, cioè nell'ipotesi della materia continua, e nell'ipotesi della materia considerata come l'aggregato di molecole distinte a piccolissime distanze: il primo invece, credendo che la supposizione della materia continua non basti a rendere ragione di tutti i fenomeni della natura, si attenne di preferenza all'altra supposizione, bramando rifare con essa da capo tutta la Meccanica. Prima dei sullodati geometri, Lagrange avea trattati vari problemi relativi alla meccanica de' solidi e de' fluidi, creando una nuova scienza per queste come per tutte le altre quistioni di equilibrio e di moto: intendo parlare della Meccanica Analitica, opera cui anche oggidì si danno molte lodi, e viene chiamata la vera meccanica filosofica ma che nel fatto si riguarda poco più che un oggetto di erudizione. Avendo io avuta nella mia prima giovinezza particolare occasione di fare su quest'opera uno studio pertinace, erami formata un'idea così elevata della generalità e della forza de' suoi metodi, che giunsi a riputarli, in confronto dei metodi antecedentemente usati, un prodigio d'invenzione non minore di quello del calcolo differenziale e integrale in confronto dell'analisi cartesiana: e pensai e scrissi essere impossibile che per l'innanzi ogni ricerca di meccanica razionale non si facesse per questa via. Esaminate in seguito le recenti memorie, e avendo notato come in esse non si faccia uso (se non forse qualche rara volta in maniera secondaria) dell'analisi che tanto mi avea colpito, credetti d'essermi ingannato, che cioè le nuove questioni di meccanica non si potessero assoggettare ai metodi della Meccanica Analitica. Provai però a convincermene anche per mezzo di un esperimento: e allora fu molta la mia sorpresa nell'accorgermi che in quella vece esse vi si accomodano egregiamente, e ne ricevono molta chiarezza: un andamento di dimostrazione che accontenta lo spirito: conferma in alcuni luoghi: cangiamento in alcuni altri: e quel che è più, aggiunta di nuovi teoremi. Ecco il motivo che mi determinò a pubblicare una serie di Memorie sull'enunciato argomento, per tentare di ridurre alla mia opinione qualche lettore: ma innanzi alle prove di fatto pensai mettere alcune riflessioni generali dirette a indicare, per quanto almeno è della mia capacità, il profondo di quella sapienza che trovasi nella maggior opera del sommo Geometra italiano. [35], pp. 201-202.

${ }^{2}$ Piola refers to Poisson, who criticized Lagrange's abstraction in Analytical Mechanics as to the constitution of natural bodies. Piola's juxtaposition of the adjectives 'rational' - to him, purely logical and undoubtable - and 'physical' - to him, coming from debatable conjectures - is apparent.

${ }^{3}$ Non vorrei io però una meccanica fisica di cui le prime equazioni ragionate sopra supposizioni alquanto incerte non ottennessero se non una lontana conferma, scendendo dal generale al particolare, per qualche corrispondenza con fenomeni osservati. La buona filosofia fatta esperta dalle aberrazioni di molti fra que' pensatori che fabbricarono sistemi intorno alle cose naturali, deduce dalla moltiplicità stessa e contrarietà delle loro opinioni, che non è retto quel metodo di filosofare il quale, senza sufficiente appoggio nel suo principio, ne ha uno soltanto nel suo fine. Se queste riflessioni sono giuste, ognun vede quanto interessi rimettere in credito e in pratica lo studio della M. A. la quale è la sola che a stabilire l'equazioni fondamentali abbisogna di pochi dati la cui verità non è disputabile. [35], p. 205.
} 
'stress') derives by suitable mathematical procedures of averaging over a unit surface. This postulate, however, stems from an unprovable analogy between planets and molecules, and suffices to describe linear elasticity only. Piola was evidently disturbed by this fact, since he wanted nothing unproved:

[Analytical mechanics] makes us put into equations facts, of which we have clear ideas, without forcing us to consider their causes, of which we have obscure ideas: certain facts instead of causes, to express the action of which we form doubtable and not too convincing hypothesis. It is a system that precisely needs only those notions to which human mind arrives with certainty, and refrains or may refrain to state, indeed, where it seems not possible to put a solid basis for our reasonings. [...] The action of inner active or passive forces [...] is sometimes such that we may get a concept of it, but more often [...] the doubt remains, that the laws of nature be well different than those lacking images by which we strive to represent them. For instance: if we deal with the motion of a point forced to stay on a surface, we may clearly represent the surface resistance as a force operating normally to the surface itself, and establish by this consideration only the general equations of motion. If, on the other hand, we deal with those forces that kept the continuity of masses in motion, I confess that, at least for me, their way to act is so twisted, that I cannot settle the ways I could imagine it. [...] But in the A. M. we watch the effect of inner forces and not the forces themselves, that is to say the equations of condition that must be satisfied, or certain functions that are varied by the forces: these effects are clear [... and] we have the same exact and certain equations that we would have by a thorough knowledge of them actions. This is the big step: we can afterwards, if we wish, dress up with the representation of forces the undetermined coefficients introduced on purpose, and then, once determined these coefficients by the mechanical equations, gain some notions about the forces themselves. ${ }^{4}$

Piola's approach is found unaltered also in contemporary handbooks of mechanics, for instance the one by Lanczos [48]:

It frequently happens that certain kinematical conditions exist between the particles of a moving system which can be stated a priori. For example, the particles of a solid body may move as if the body were "rigid" [...]. Such kinematical conditions do not actually exist on a a priori grounds. They are maintained by strong forces. It is of great advantage, however, that the analytical treatment does not require the knowledge of these forces, but can take the given kinematical conditions for granted. We can develop the dynamical equations of a rigid body without knowing what forces produce the rigidity of the body. ${ }^{5}$

Thus, the idea of physical evident conditions turned into mathematics is basic in Piola's mechanics: to see facts and detect empirically shared truths only, and put them into undoubtable equations, seems modern, and difficult to contest even nowadays. This remained a corner stone in all of Piola's papers, where he tried to broaden and improve his statements, leaving nothing uncertain, at least for his standards.

In his work of 1833 [35] Piola made clear both his philosophical points of view and his approach to the mechanics of continuous media, by starting to describe rigid bodies. Indeed, in this case the undoubtable condition equations exist, that (in a contemporary language) Euclidean metrics is preserved passing from reference to present configuration. Since Piola's original equations are written in components with respect to Cartesian rectangular coordinates, writing them in full would be rather lengthy and could obscure their actual meaning. Thus, I prefer a shorter and more suggestive form, that is, contemporary and absolute notation, which I will keep henceforth in order to simplify the typographical output. For a visual comparison between the outputs of these two different notations, check $[40,16]$.

Piola's conditions of rigidity coincide with

$$
\mathbf{C}=\mathbf{F}^{\top} \mathbf{F}=\mathbf{I}, \quad \mathbf{B}=\mathbf{F F}^{\top}=\mathbf{I}
$$

where $\mathbf{F}$ is the list of the partial derivatives of the transformation of the coordinates of each point from the present to the actual shape, that is, in contemporary language, the transformation gradient.

Lagrange in his Analytical Mechanics [39] had introduced constraint reactions as 'passive' forces emerging when condition equations tend to be violated. Their effect on the considered system is accounted for by introducing an additional term in what we now call virtual work ('moment', according to Lagrange) of all forces, built by the linear product of an unknown multiplier times the first variation of the condition equation. This equals to see all inner forces in a system as those 'passive' forces emerging when one isolates an element of the system and considers its balance under rigid body motions ("principle of solidification"; see also [40]).

\footnotetext{
${ }^{4}[\ldots]$ ci fa mettere in equazione fatti di cui abbiamo idee chiare senza obbligarci a considerare le cagioni di cui abbiamo idee oscure: fatti certi invece di cagioni a esprimere l'azione delle quali si formano ipotesi dubbie e non troppo persuadenti. È desso un sistema che abbisogna appunto di quelle sole cognizioni a cui arriva la mente umana con sicurezza, e si astiene o può astenersi dal pronunciare appunto dove non pare possibile mettere un fondo sodo ai nostri ragionamenti. [...] L'azione delle forze interne attive o passive [...] è qualche volta tale che possiamo farcene un concetto, ma il più sovente rimane [...] il dubbio che il magistero della natura sia ben diverso da quelle immagini manchevoli colle quali ci sforziamo di rappresentarcelo. Per un esempio: se trattisi del moto di un punto obbligato a stare sopra una superficie, possiamo rappresentarci con chiarezza la resistenza della superficie siccome una forza che opera normalmente alla superficie stessa, e stabilire con questa sola considerazione le equazioni generali del moto. Se trattasi invece di quelle forze che mantengono la continuità nelle masse in moto, io confesso che, almeno per me, il loro modo d'agire è sì inviluppato, che non posso accontentarmi alle maniere con cui vorrei immaginarmelo. [...] Ma nella M. A. si contemplano gli effetti delle forze interne e non le forze stesse, vale a dire le equazioni di condizione che debbono essere soddisfatte, o certe funzioni che dalle forze sono fatte variare: questi effetti sono chiari [...e] si hanno le stesse equazioni sicure ed esatte che si avrebbero da una perspicua cognizione di esse azioni. Ecco il gran passo: si può poi, se si vuole, rivestire della rappresentazione delle forze i coefficienti indeterminati introdotti in maniera strumentale, e allora, determinati questi coefficienti a posteriori mediante le equazioni meccaniche, acquistare delle cognizioni intorno alle forze stesse. [35], pp. 204-205.

${ }^{5}$ [48], pp. 4-5.
} 
In order to apply Lagrange's techniques, thus, Piola wrote what we now interpret as the virtual work spent on the possible violations of the rigidity constraint, i.e., on the first variation of the quantities provided by (1):

$$
\delta \mathbf{C}=\left(\delta \mathbf{F}^{\top}\right) \mathbf{F}+\mathbf{F}^{\top}(\delta \mathbf{F})=\mathbf{0}, \quad \delta \mathbf{B}=(\delta \mathbf{F}) \mathbf{F}^{\top}+\mathbf{F}\left(\delta \mathbf{F}^{\top}\right)=\mathbf{0}
$$

The scalar components of the symmetric tensors in (2) are six, while three suffice to make the problem kinematically determinate, i.e., to uniquely determine the three cartesian components of the transformation from the reference to the present configuration, modulo the necessary, but immaterial, integration constants. Thus, as we say nowadays, a rigid body is internally over-constrained, or redundant; however, Piola had no clear idea of this fact and advanced some not well explained statements on the number of necessary and sufficient condition equations to provide. Such a remark on Piola's unclearness is found also in the well known monograph by Todhunter and Pearson [11]. Quite likely, as it will be apparent also below, Piola wanted to find, beyond any reasonable doubt, which, and how many, condition equations can in general be provided for an extended body.

By (2), Piola could write the moments (i.e., the virtual work) of all forces, active (called, along with the tradition of the time, "accelerating") and passive. In particular, the moment of passive forces is provided by the product of the elements of two sets of six Lagrange multipliers, that we suitably list in the symmetric tensors $\mathbf{T}$ and $\mathbf{P}_{2}$, times the six components of $\delta \mathbf{B}$ and $\delta \mathbf{C}$ in $(2)$, respectively. Indeed, at least in in [35] Piola did not make any difference between $\delta \mathbf{B}$ and $\delta \mathbf{C}$ in (2): both represented to him first-order variation of well-established and undoubted condition equations, and he did not bother to check about their actual kinematical meaning.

Piola then adopted standard techniques of calculus derived by Lagrange, and localization made him able to obtain the local balance equations

$$
\operatorname{Div}(\mathbf{T F})+\varrho J \mathbf{f}=\mathbf{0}, \quad \operatorname{Div}\left(\mathbf{F P}_{2}\right)+\varrho J \mathbf{f}=\mathbf{0}
$$

where: $\varrho$ is the mass per unit volume in the present configuration, $\mathbf{f}$ is the active force per unit volume in the present configuration, and $J=\operatorname{det} \mathbf{F}$, called "sextinomial" by Piola, makes it possible to transform the volume unit from the present to the reference shape (a concept introduced by Lagrange in hydrodynamics, in order to simplify the writing of balance equations). In addition, Div and div are the divergence operators in the reference and in the present configurations, respectively. Remark that the localization of the integrals providing the virtual work of a continuous system to a volume particle, which is a standard tool of what we now call calculus of variations, translates the fundamental 'principle of solidification', quoted above: we admit that we may isolate a particle inside a volume and deal with it as if it were rigid [40].

In contemporary continuum mechanics of deformable bodies, we accept the validity of the second set of (3) only, because of the different meaning of the condition equations (2). Indeed, in rigid motions it is immaterial to adopt $\mathbf{B}$ or $\mathbf{C}$ as condition equations: the gradient of a rigid transformation is orthogonal and its inverse and transpose coincide. On the other hand, in general motions this does not happen, and $\mathbf{C}$ characterizes metrics in the present configuration, while it is $\mathbf{B}^{-1}$, and not $\mathbf{B}$, that characterizes metrics in the reference configuration. This comment is actually a detail if we think of the very powerful step attempted by Piola; what is apparent, and somehow surprising, is Piola's attitude towards his results.

First, he did not bother in checking the consequences of its variational procedure at the boundary of the body; he said he would deal with them in following papers, without any specification on the reasons of such a decision. Indeed, from a contemporary point of view, boundary terms are essential in characterizing the flow of physical quantities of interest into the considered region, but Piola seemed not worried about this particular question, and focused on bulk equations only.

Second, Piola had obtained balance equations in the reference configuration, where he could write undoubtable and inalterable condition equations more easily, following Lagrange's techniques and examples in hydrodynamics. On the other hand, his French contemporaries had obtained balance equations in the present shape of the body. Quite likely, Piola did not realize he had found something original and very important for applications, since the pull-back of quantities from the present to the reference configuration is fundamental in all processes involving finite deformations. He wanted simply to compare his result with Cauchy's and Poisson's, and, on this purpose, he derived an original formula. Due to his relative isolation in the European world of academic mechanicians, strongly bound to the French and English universities and scholar institutions (Germany would emerge formidably only in the second half of the century), this formula is rarely attributed to him. It made him able to transform volume integrals defined over the actual shape into similar integrals defined over the reference one, and reads

$$
\operatorname{Div}\left(\mathbf{L} J \mathbf{F}^{-\top}\right)=J \operatorname{div} \mathbf{L}
$$

for each symmetric tensor $\mathbf{L}$. 
By means of (4), Piola easily obtained local balance equations in the same form of his famous French contemporaries, i.e.: ${ }^{6}$

$$
\operatorname{div} \mathbf{T}+\varrho \mathbf{f}=\mathbf{0}, \quad J \mathbf{T}=\mathbf{F P}_{2} \mathbf{F}^{\top},
$$

but immediately put into evidence his contribution of generality:

Remark the perfect concurrence of this result with that obtained by the two famous geometers quoted at the beginning of the introduction [Cauchy and Poisson] following completely different reasonings [...] I recommend to note that in my analysis $A, B, C, D, E, F$ [the components of $\mathbf{T}$ ] are not pressures acting on different planes, but are coefficients, to which I also will attach a representation of forces according to what will seem more natural to me $[\ldots]^{7}$

It is apparent by this quotation that Piola thought it more important to show that Lagrange's techniques were so powerful to encompass the results by Cauchy and Poisson, rather than stressing the fact that he had obtained an absolutely original result, that is, local balance equations pulled back in the reference shape. To him, originality lay only in applying successfully the procedures of the Analytical mechanics without accepting obscure hypotheses on the mysterious nature of forces. The key point of Piola's mechanics emerging from this paper is that inner forces are simply reactions of suitable constraint equations; it is slowly, but finely, perfected in his following memoirs.

\section{Constitutive arguments separated from balance equations}

In his work of 1836 [36] Piola made what may seem a temporary digression in his personal path in mechanics. Indeed, he built a very refined procedure of calculus of finite differences ${ }^{8}$ to be able to apply Lagrange's techniques and re-obtain Poisson's results on continuum mechanics based on molecular actions. Actually, in [35] he had focused on kinematics and balance only, thus, he had clear in mind that he could not fully represent all the powerful description of linear elasticity provided by his French contemporary. This paper is, then, the proof to everybody that he could actually recover Poisson's equations, but that the structure of keeping kinematics separated from balance, following Lagrange, remained unaltered. One sees again Piola's formidable desire to show the absolute generality of Analytical mechanics, encompassing even Poisson's results, that the latter claimed to be different from Lagrange's because they were based on a seemingly more realistic "physical mechanics", juxtaposed to the purely abstract "analytical mechanics" [10].

What seems very important, original, and long-lasting in this paper is Piola's introduction of the idea of ideal disposition, a particular kind of reference configuration, totally abstract form the mechanical point of view. This shape is very useful for Piola's mathematical procedures of finite differences, but actually turns out to be very useful in general, as we will see. In Piola's words, if $a, b, c$ are the set of reference Cartesian coordinates, this shape is an

$[\ldots]$ ideal disposition antecedent to the actual state, in which the matter of the body itself was contained in a parallelepyped [...] and all the $a$ differ among them but for increments equal to $\alpha$, the $b$ for increments equal to $\beta$, the $c$ for increments equal to $\gamma[\ldots] .{ }^{9}$

In this way, such a configuration may be meshed uniformly by the coordinates $a, b, c$, and

[... keeping into account] the irregularity required by the discontinuity of matter, [...] I obtain a regularity [...] necessary for the procedure of calculation like that used by Lagrange in the Analytical mechanics. ${ }^{10}$

This idea is incredibly acute and powerful: a contemporary scholar in continuum mechanics would easily recognize in such a concept the ideal natural state as proposed, for instance, by Truesdell and Noll [22]: a fictitious configuration, suitable only for mathematical purposes, in which the body may be thought at rest and stress-free because of the regular, natural arrangement of its particles. It is also interesting to remark that similar ideas of regular disposition would appear in the well known monograph in crystallography by Bravais [49] to justify the actual behaviour of many physical bodies. Again, as a characteristic of all of Piola's work, this attribution of originality is missing in international literature because of Piola's isolation in a scientific world dominated by languages other than Italian. Some more considerations on Piola's attitude towards international publication and spreading of scientific ideas is found in [47].

\footnotetext{
${ }^{6}$ Nowadays we call T Cauchy's stress tensor, while we call $\mathbf{P}_{1}=\mathbf{F P}_{2}, \mathbf{P}_{2}$ first and second Piola stress tensors, respectively. Usually the name of Kirchhoff is juxtaposed to Piola's in qualifying the stress tensors in the reference shape; this sounds historically only partially correct. Some more hints on the subject are in $[40,16]$.

${ }^{7}$ Osservisi la perfetta coincidenza di questo risultato con quello ottenuto dai due celebri geometri citati dal principio dell'introduzione dietro ragionamenti affatto diversi [...]. Raccomando di notare che nella mia analisi le $A, B, C, D, E, F$ non sono pressioni che si esercitino sopra diversi piani, ma sono coefficienti, cui nel seguito attaccherò io pure una rappresentazione di forze secondo mi sembrerà più naturale [...][35], p. 220.

${ }^{8} \mathrm{~A}$ detailed exposition of all his original results in this field is found in [11].

${ }^{9}[. .$.$] disposizione ideale antecedente allo stato vero nella quale la materia del corpo stesso era contenuta in un parallelepipedo [...] e tutte le a$ non diversificano fra loro che di aumenti eguali ad $\alpha$, le $b$ di aumenti eguali a $\beta$, le $c$ di aumenti eguali a $\gamma[\ldots] .[36]$, p. 167.

${ }^{10}[\ldots]$ l'irregolarità voluta dalla discontinuità della materia, [...] ottengo una regolarità [...] necessaria pel meccanismo del calcolo quale è adoperato da Lagrange nella Meccanica analitica.[36], p. 167.
} 
The first two sections of [36] is, thus, devoted to an over-long succession of finite differences calculations and power series expansions, aimed at proving that, by the same physical hypothesis adopted by Poisson, ${ }^{11}$ Piola could provide the same equations, without abandoning Lagrange's techniques, and leaving physical hypotheses on the very nature of inner forces to a subsequent part of the mechanical theory.

Indeed, after the first two sections of this memoir, where he developed his constitutive arguments based on the integration and the averaging of discrete quantities, Piola could still apply Lagrange's formulation of virtual work, without the need of introducing condition equations. As a matter of fact, now inner forces are no more seen as constraint reactions, but are constitutively prescribed. Piola could then obtain again the local balance equation in the ideal reference configuration

$$
\operatorname{Div}\left(\mathbf{P}_{1}\right)+\mathbf{f}=\mathbf{0}, \quad \mathbf{P}_{1}=\mathbf{F P}_{2}
$$

where the term $\varrho J$ is now missing with respect to the analogous equation (3) because mass density is supposed uniformly equal to unity in the ideal reference state. Since the ideal state is in principle an abstraction, Piola pulled his balance equation (6) in the present configuration by means of his transport theorem (4), re-obtaining the well known Poisson's equations

$$
\operatorname{div} \mathbf{T}+\varrho \mathbf{f}=\mathbf{0}, \quad \mathbf{T}=\varrho \mathbf{P}_{1} \mathbf{F}
$$

and this time providing an interpretation for the components of $\mathbf{P}_{1}$. Indeed, Piola stated that they are functions of the coordinates in the ideal state representing the components of 'pressure' on planes through the point in the present configuration corresponding to planes through the same point in the ideal state.

Strangely enough, in this memoir Piola seems to tribute the paternity of molecular elasticity to Poisson only, while we know that Cauchy as well considered discrete and continuous distributions of matter. Maybe he did not want to enter a discussion with the latter, whom he had a high esteem of and who was in voluntary exile in Italy at the time in which the memoir was prepared; the reference point of Cauchy's exile in Italy was Piola himself, as it is historically proved [52, 53].

In any case, as already said, this memoir actually represents only a temporary digression in Piola's path, apparently a stop to admit that a discussion with European scholars was necessary to prove that Italian scientists could be up-to-date and still original. Piola soon turned back to his Lagrangean approach, and reflected quite a long time before presenting his two most mature memoirs.

\section{The return to a pure Lagrangean approach}

Piola summed up his original and everlasting contributions in his last two papers on continuum mechanics [37, 38]. They appeared quite a long time after the first ones, and one of hem was published posthumously, edited by his former pupil Francesco Brioschi. This is for sure a sign of a long meditation on the subject, helped by contemporary differential and integral calculus, for instance by Lacroix [50] and Bordoni [51], improved with respect to Lagrange. Piola's meditation derived, for sure, from his always declared desire to leave nothing uncertain and unproved, and from his own realization of some weaknesses in his previous writings:

Indeed, I do not hide now that in my previous writings some ideas were not exposed with sufficient maturity: we have some too advanced, we have some other too fearful: certain parts of those writings might have been omitted, [...] a fortiori those other that [...] I feel bound not to repeat anymore $[\ldots]^{12}$

Thus, Piola's intention in his last works was fore sure to re-write his mechanics in order to sweep all possible doubts away. In [37] he put forth precise (even for a contemporary scholar on continuum mechanics) definitions of ambient space, of continuum models and of the radical difference between physical points and geometrical places: such definitions are those commonly accepted also in contemporary textbooks. Afterwards, he recalled his ideas on the natural, ideal disposition, with uniform mass density equal to unity, remarking that it is just a useful concept, not pretending to reflect any physical truth:

This way of conceiving the structure of different bodies is what suffices to the Mathematician wishing to put their equilibria and motions into equations. It is correct to move further for the need of the Physicist, and call molecules those material points [...] of such thinness that it is not possible for our senses, be they also a hundred times more acute, to remark in them distinctions of parts. He can also imagine any of these molecules composed by [...] particles (called atoms) not separable if not by means of another kind of forces different from those considered in Mechanics, that is, chemical forces: and then put into this second sort of particles that absolute invariability that the Mechanician supposes just in the molecules. The Metaphysicist goes, if he wishes, further: to him one of these atoms [...] may be

\footnotetext{
${ }^{11}$ That is, that molecules are corpuscles very close to each other and interact by central forces, which are attractive within a certain range of value of this distance, repulsive when the distance becomes too small, and vanish when this distance reaches a sensible value, called radius of the sphere of molecular action.

${ }^{12}$ Perocchè non dissimulo accorgermi ora che ne' precedenti miei scritti alcune idee non furono esposte con sufficiente maturità: ve ne ha qualcuna troppo spinta, ve ne ha qualch'altra troppo timorosa: certe parti di quelle scritture potevano essere ommesse, [...] a più forte ragione quelle altre che [...] non mi sentirei più di ripetere $[\ldots][37]$, pp. $1-2$.
} 
enlarged into almost a world, so that it is possible to consider in them a number, large at will, of points now imagined without extension, issuing forces keeping them always at inalterable distances [...] ${ }^{13}$

It is scarcely to remark how modern this vision is, even if it dates back to 1845 (the paper was published in 1848, but actually submitted in 1845). Then, Piola defined mass density and the transformation rules for volume units, for one-, two-, and three-dimensional continua, thus showing that there is no distinction between continuum models, at least in principle. By these, he derived a modern expression of the equation of mass continuity for continua of different dimensions. Then, he made precise considerations on metrics and density to define generalized volume actions ("accelerating forces") and, to introduce a presentation of the techniques of analytical mechanics as wide as possible, he began by investigating a thread ("filo materiale").

Piola then recalled his procedure on rigid bodies and, with a clear maturity, proved that the expressions providing the condition equations for rigidity are the first variations of quantities that he calls "trinomials" and we nowadays recognize, in a three-dimensional ambient space, as the six components of the Cauchy-Green strain tensor $\mathbf{C}=\mathbf{F}^{\top} \mathbf{F}$. In this way, he overpassed the ambiguity he had kept in [35] making no distinction between $\mathbf{B}$ and $\mathbf{C}$ in (1). He then presented the balance equations for rigid bodies, this time providing also the contributions of boundary terms, that he had neglected in [35]. In addition, Piola presented a precise description of a rigid velocity and acceleration field, remarking on the expression that a rigid body velocity field superposed on a body configuration shall have.

Piola now knew that condition equations for a deformable body cannot be provided in general, thus he introduced a trick, quite probably inspired by the results of his French acquaintance Cauchy. ${ }^{14}$ Indeed, Cauchy [54] had proved what is now known as theorem of polar decomposition (see, for instance, [21, 22, 23]): the present configuration of a continuum is reached via the composition of a pure stretch and a rotation (or vice versa). Thus, here is Piola's trick: we may imagine that there exists an intermediate configuration between the ideal and the present one, and that the transformation leading from the intermediate to the present shape is rigid. Then, there is the possibility of writing the undoubtable condition equations for rigidity, and all the balance equations for the body are immediately found via Lagrange's procedure, in the same way as Piola did in his work [35]. Piola easily pushed his equations forward to the present configuration by means of his transformation theorem (4), proving them to be equivalent to the ones provided by Cauchy. Moreover, he managed the boundary terms, which he had neglected in [35], and which are expressed by surface integrals on the body contour: by the calculus of variations, he immediately derived Cauchy's theorem of the tetrahedron on the representation of stress, and commented that

[...] the said six quantities [the Lagrange multipliers of the condition equations of rigidity] in both cases [the intermediate and the present configurations] are the analytical expressions containing the whole of the effect of all the inner actions on the generic point ( $p, q, r)$ [in the intermediate configuration] or $(x, y, z)$ [in the present configuration] [... $]^{15}$

Thus, Piola had come to a satisfactory point, at least for his philosophical projects on mechanics: he had shown that an acceptable trick, that does not limit the generality of the method, lets one find well known and recognized balance equations for well identified terms representing contact actions. He was, however, aware that his position was original, remarked that all his conclusions descended from a single principle, and

[...] such a principle consists in framing any system with respect to two triads of orthogonal axes: it may be used in two ways, [...] in a first way [...] with the aim of proving the principle of virtual velocities, and also the other ones, of conservation of the motion of the centre of gravity, and of areas. ${ }^{16}$ In such a case, instead of conceiving the $\delta x, \delta y, \delta z$ of the various points of the system as virtual velocities, or infinitesimal spaces described by that fictitious motion [...], it is much more natural to imagine them as increments taken by tha coordinates of the above said points when the system is referred to other three orthogonal axes very close to the first ones, like the former had moved very little [...] one may then understand how the increments of the coordinates take place without alterations of the reciprocal actions of the parts of the system on each other [...]. The simultaneous framing of the system with respect to two triads of orthogonal axes plays effectively in another way [...]. Here we mean to talk about the method that leaves $\delta x, \delta y, \delta z$ at all general, and deals with condition equations, introducing indeterminate multipliers. In such a case, considering the two triads is very helpful for establishing condition equations, that otherwise one cannot provide in general [...]. It seems to me that Lagrange and other Geometers missed such a point of view: what might deserve more attention in the present Memoir refers to it. ${ }^{17}$

\footnotetext{
${ }^{13}$ Questa maniera di concepire la struttura dei differenti corpi, è quanto basta al Matematico che vuole metterne in equazione gli equilibrj e i movimenti. Pei bisogni del Fisico è permesso andare innanzi, e quei punti materiali chiamarli molecole [...] di tale esilità che non sia possibile ai nostri sensi, fossero anche le cento volte più perfetti, notarvi distinzioni di parti. Può anche immaginare ciascuna di queste molecole composta di [...] particelle (chiamate atomi) [...] non separabili se non per mezzo di un altro genere di forze diverse da quelle che si considerano in Meccanica, cioè da forze chimiche: e quindi respingere a questa seconda sorta di particelle quella assoluta invariabilità che il Meccanico può supporre addirittura nelle molecole. Il Metafisico va, se gli piace, ancora più innanzi: per lui uno di questi atomi $[\ldots]$ può ingrandirsi ancora quasi un mondo, sì che sia lecito considerarvi per entro un numero quanto vuolsi grande di punti ridotti adesso affatto inestesi, da cui emanino forze che li tengano a distanze sempre inalterabili [...][37], p. 9.

${ }^{14}$ As already hinted, Piola was in close relationship with Cauchy, and was also his reference during Cauchy's exile in Italy (1830-1833). For more information and details, among which some letters between the two, see Bottazzini [52] and Dahan Dalmedico [53].

${ }^{15}[\ldots]$ le mentovate sei quantità in ambi i casi sono le espressioni analitiche contenenti l'effetto complessivo di tutte le azioni interne sopra il punto generico $(p, q, r)$ ovvero $(x, y, z)[\ldots][37]$, p. 101.

${ }^{16}$ Piola meant the vanishing of the virtual power on rigid motions, the conservation of momentum and of moment of momentum.

${ }^{17}[. .$.$] tal principio sta nel riferimento simultaneo di un qualunque sistema a due terne di assi ortogonali: esso può adoperarsi in due maniere [...] in una prima$ maniera [...] a fine di dimostrare il principio delle velocità virtuali, e anche gli altri della conservazione del moto del centro di gravitå, e delle aree. Invece di
} 
That is, balance equations can be obtained by superposing an infinitesimal, fictitious, rigid motion to the present configuration of the

body. The same happens also if we consider the actual configuration with respect to two different Cartesian frames (nowadays we would call them 'observers') shifted by an infinitesimal amount. This can be done irrespective of the constitutive relations characterizing inner contact forces, thus remaining as indeterminate Lagrange multipliers of known condition equations. In the remaining of this very long memoir, Piola extended his results to fluid, remarking that the differences between the two subjects should be of constitutive nature only, and re-obtained the expressions for elastic forces by the same procedure he had already adopted in [36].

\section{Piola's swan song}

In his last paper [38], edited posthumously by Francesco Brioschi, Piola continued his ever-lasting attempt to polish his presentation of mechanics and leave nothing uncertain and unproved. This time, apart from a general and more mature re-writing of his procedures, he focused on what, according to him, remained obscure in Lagrange's technique of analytical mechanics. Indeed, in the introduction to the memoir he stated that

[Following Lagrange, if we admit] the existence of inner forces among the various physical points of a system, it is not difficult to recognize some functions (like those expressing distances, angles, and so on), the values of which are altered by the actual exercise of those forces; well, the author wants us to multiply the variations of those functions by indeterminate coefficients, and to introduce the products in the general equation of Analytical Mechanics, precisely as we would have done, according to the known method, if those functions were the left hand sides of condition equations reduced to zero. Here we understand at once the amplitude and the excellence of the principle: but at the same time we feel the need of a proof that persuades us of its truth: and even supposed this, we still find lacking the exposition, though. Indeed, there may be at the same time many expressions of quantities that the inner forces of a system tend to vary: which of them shall we take, which shall we omit? Who assures us that, by using many of these functions subjected to changes by the action of inner forces, we do not make useless repetitions, in expressing by means of some an effect already written by others? And cannot it happen instead that we omit some of these necessary to be introduced so that the total effect of inner forces be wholly expressed? It is well true that we come to infer by some passages of the A. M. that the functions to be adopted in the more general cases are then the same which remain constant in other more particular cases, i.e., when we deal with rigid bodies, inextensible threads, incompressible fluids: yet this also is a glimpsed, but not proved, property of such functions. To sum up, to a good establishment of the principle under discussion, we still miss two things: firstly, a proof resulting persuasive, afterwards a criterion to distinguish which and how many should be the functions to put into play with the aim of wholly describing the action of the inner forces of systems. ${ }^{18}$

Thus, the actual problem that Piola found unsolved was to determine without any doubt which functions should be taken for cranking the well marching wheel of analytical mechanics. All of his preceding work, then, was simply preparatory, and his final effort should have been to make this last point clear, because all the rest led to the well known balance equations (bulk and boundary) without any problem.

Piola began his memoir by stating again that the actual thing to do is to consider the actual configuration with respect to two frames of reference:

If we call $x, y, z$ the coordinates of the generic point, the pertaining variations $\delta x, \delta y, \delta z[\ldots]$ can, without endangering generality, be considered those provided by the very little increments $i \delta x, i \delta y, i \delta z$ that would take the coordinates $x, y, z$ when the system be referred to three other rectangular axes very little far apart, either for the origin and for the three directions, from those primarily assumed by the $x, y, z$, like those had moved by a very little quantity. ${ }^{19}$

concepire in tal caso le $\delta x, \delta y, \delta z$ dei diversi punti del sistema come velocità virtuali o spazietti infinitesimi descritti in virtù di quel moto fittizio [...], è assai più naturale [...] il ravvisarle quali aumenti che prendono le coordinate degli anzidetti punti quando il sistema si riferisce ad altri tre assi ortogonali vicinissimi ai primi, come se questi si fossero di pochissimo spostati. [...] allora si capisce chiaro come gli aumenti delle coordinate abbiano luogo senza alterazioni nelle azioni reciproche delle parti del sistema le une sulle altre [...] Il riferimento simultaneo del sistema a due terne di assi ortogonali giuoca poi efficacemente in un'altra maniera [...]. Qui s'intende parlare di quel metodo che lascia alle $\delta x, \delta y, \delta z$ tutta la loro generalità e tratta le equazioni di condizione, introducendo moltiplicatori indeterminati. In tal caso la contemplazione delle due terne di assi giova per l'impianto delle dette equazioni di condizione, che altrimenti non si saprebbero assegnare in generale [...]. Un tal punto di vista parmi sfuggito a Lagrange e ad altri Geometri: a esso si riferisce quanto nella presente Memoria può essere più meritevole di attenzione.[37], pp. 110-111.

${ }^{18}$ Supposta l'esistenza di forze interne fra i vari punti fisici di un sistema, non è difficile riconoscere alcune funzioni (come espressioni di distanze, di angoli, ec.), i valori delle quali vengono alterati dall'attuale esercizio di quelle forze; or bene, l'autore vuole che moltiplichiamo per coefficienti indeterminati le variate di quelle funzioni, e ne introduciamo i prodotti nell'equazione generale della Meccanica Analitica, precisamente come avremmo fatto, secondo il metodo noto, se quelle funzioni avessero costituito i primi membri di equazioni di condizione ridotte a zero. Qui si capisce subito la vastità e l'eccellenza del principio: ma nello stesso tempo si sente il bisogno di una dimostrazione che ce ne persuada della realtà: e questa anche ammessa, ne troviamo tuttavia mancante l'esposizione. Infatti molte possono essere contemporaneamente le espressioni di quantità che leforze interne di un sistema tendono a far variare; quali di esse prenderemo, quali ommetteremo? Chi ci assicura che adoperando parecchie di tali funzioni soggette a mutamenti per l'azione delle forze interne, non facciamo ripetizioni inutili, esprimendo per mezzo di alcune un effetto già scritto con altre? E non potrebbe invece accadere che ommettessimo di quelle necessarie a introdursi affinché l'effetto complessivo delle forze interne venga espresso totalmente? Ben è vero che da varii passi della M. A. si arriva ad intendere come le funzioni da adoperarsi nei casi più generali siano poi le medesime che rimangono costanti in altri casi più ristretti, quando cioè trattasi di corpi rigidi, di fili inestensibili, di fluidi incompressibili: però anche questa è una proprietà di tali funzioni intraveduta ma non dimostrata. Insomma, a ben stabilire l'uso del principio in discorso, due cose ancora ci mancano: primieramente una dimostrazione che riesca persuadente, poscia un criterio per discernere quali e quante debbano essere le funzioni da mettersi in giuoco a fine di esprimere completamente l'azione delle forze interne dei sistemi.[38], pp. 390-391.

${ }^{19}$ Se chiamansi $x, y, z$ le coordinate del punto generico, le rispettive variazioni $\delta x, \delta y, \delta z[\ldots]$ possono, senza nuocere alla generalità, essere ritenute quelle somministrateci dagli aumenti piccolissimi $i \delta x, i \delta y, i \delta z$ che prenderebbero le coordinate $x, y, z$ quando il sistema si riferisse a tre altri assi rettangolari lontani assai poco, tanto per l'origine quanto per le direzioni, da quelli primieramente assunti dalle $x, y, z$, come se questi si fossero di pochissimo smossi.[38], p. 392. 
Indeed, Piola proved that by writing the condition of rigidity of the shift in the Cartesian frame of reference thus described, he obtained exactly the same expressions provided by the condition equations introduced by his former trick of imagining an intermediate configuration.

He wrote

Remark well: these right hand sides vanish in the operation indicated by the characteristic $\delta$ not because they are absolutely constant, as [...] in rigid systems [...]: on the contrary, they are most often variable, for instance in the case of fluids, but they are variable due to other quantities [...] that are not those by varying which the variations $\delta x, \delta y, \delta z$ are produced, that is, the usual $f, g, h, \alpha_{1}{ }^{20}$, and so on. Those twelve quantities being absent in those right hand sides, they go away when we derive according to $\delta$, like when they are absolutely constant, and here is the motivation of that property that in the preamble of the Memoir we said glimpsed but not proved. ${ }^{21}$

That is, Piola was aware that one cannot imagine condition equations for generic deformable bodies, yet he found it impossible that the powerful tools of analytical mechanics could not yield fruitful results for continuum mechanics as well, and employed rigidity by a change of frame. In addition, Piola claimed that only the six equations expressed by the first of equations (2) are necessary and sufficient to be inserted into the apparatus of analytical mechanics, since the other possible combinations of the products of derivatives of the position depend on them, and suggested a proof. Then, he moved on to obtain again bulk and boundary balance equations, both in the present and in the ideal configuration, remarking that the Lagrange multipliers of his procedure (i.e., the components of stress) could be explained in function of each other by the third of the equations (5), expressing the relations between what we now call referential and present stress. Piola then moved on to obtain balance equations for surface and linear systems with analogous procedures, and once again claimed his originality:

I foresee an objection. It comes out from our analysis that also for whatever body we may assume that the variations have the values (12) n. $3:^{22}$ now, Lagrange and others said such values to belong only to solid ${ }^{23}$ bodies, to rigid surfaces and lines: how, then, shall they be assumed as general? I answer: I never said that the coordinate increments in fluid systems of internally mutable in whatever way shall always receive, also as a consequence of intestine motion, values of the form of the above quoted (12), as it happens in the true motion of rigid systems; I said that such is the form that they receive as a consequence of that motion of the axes giving origin to the variations, as we explained many times above. A distinction is essential here: the true motion produced by the set of forces on the molecules of the system is other than the fictitious motion of the axes: both produce increments of the coordinates $x, y, z$ of the generic point, but right because the motions are different, these increments can be included the ones in the others, and may be excluded: when they are included, the variations $\delta x, \delta y, \delta z$ may be changed into the three velocities $u, v, w$ along the three axes, in other cases this is not possible any more. ${ }^{24}$

After a long recall of the procedure to obtain the inner forces as derived from molecular interactions depending on distance, that he had presented for the first time in his memoir of 1836, Piola begun the second part of this memoir by a powerful, and still valid today, statement:

The concept that Lagrange wanted us to figure about forces, and that we presented in the foreword, is more general than the universally accepted one. It is easily understood by everybody the force to be a cause that, by means of its variation, changes the magnitude of certain quantities. In the most obvious case, when it brings a body or a material point near another, it changes distances, that is, it makes lengths of straight lines vary: but it may instead make an angle, a density, and so on, change. In these other cases the way the forces act remains obscure, while it seems clear to us in the first case: but maybe the reason of this is extrinsic to the nature of forces. Indeed, even in that first case we do not understand how can the force instill its action in the body so that it decreases or increases the distance from another body: nevertheless, we continuously see the fact: daily observation quells in us the will to search further. If, then, carefully investigating, we find that here also the way the forces act is mysterious, no wonder that it appears obscure to us in the other cases. Wishing to reduce the action of forces to that decreasing a distance is making a wider concept smaller, is wishing to recognize but a particular class of forces. Generally speaking, to which point may we push our knowledge about the causes we submit to measure? maybe so that we understand their intimate nature, and the true way in which they act? never. Newton wrote: Caveat lector ne per

${ }^{20}$ The coefficients describing the change of Cartesian triad.

${ }^{21}$ Notisi bene: questi secondi membri svaniscono nell'operazione indicata dalla caratteristica $\delta$, non perché siano assolutamente costanti, come [...] pei sistemi rigidi: sono anzi il più spesso variabili, per esempio nel caso de' fluidi, ma sono variabili pel variare di tutt'altre quantità, che non sian quelle al variar delle quali è dovuto il prodursi delle variazioni $\delta x, \delta y, \delta z$, cioè le solite dodici $f, g, h, \alpha_{1}$, ec. Stante l'assenza di tali dodici quantità da quei secondi membri, essi vanno via mentre si deriva secondo $\delta$, come quando sono assolutamente costanti, ed ecco la ragione di quella proprietà che nel preambolo della Memoria dicemmo intraveduta ma non dimostrata.[38], p. 397.

${ }^{22}$ Those describing the change of Cartesian triad.

${ }^{23}$ Piola's, among others', synonym for rigid.

${ }^{24}$ Prevedo un'objezione. Risulta dalla nostra analisi che eziandio per corpi qualunque possiamo supporre che le variazioni abbiano i valori (12) n. 3: ora Lagrange ed altri dissero tali valori appartenere soltanto ai corpi solidi, alle superficie o linee rigide: come dunque si assumono generali? Rispondo: io non dissi mai che gli aumenti delle coordinate nei sistemi fluidi o mutabili internamente in qualsivoglia modo debbano sempre ricevere, anche in conseguenza di un moto intestino, valori della forma dei (12) succitati, come avviene nel moto vero de' sistemi rigidi; dissi che tale è la forma che ricevono in conseguenza di quel moto degli assi che dà origine alle variazioni, come sopra si è più volte spiegato. È qui essenziale una distinzione: altro è il moto vero prodotto dall'insieme delle forza sulle molecole del sistema, altro il moto fittizio degli assi: entrambi producono aumenti alle coordinate $x, y, z$ del punto generico, ma appunto perché i moti sono diversi, questi aumenti possono comprendersi gli uni gli altri, e possono escludersi: quando si comprendono, le variazioni $\delta x, \delta y, \delta z$ possono mutarsi nelle tre velocità $u, v, w$ secondo i tre assi, in altri casi ciò non è più permesso.[38], pp. 421-422. 
hujusmodi voces cogitet me speciem vel modum actionis causamve aut rationem physicam alicubi definire, vel centris (quœe sunt puncta mathematica) vires vere et physice tribuere, si forte aut centra trahere, aut vires centrorum esse dixero (Princ. Math. I., 1 . $^{\text {st }}$, Def. VIII at the end). Collected all is unknown in the measure units of the same kind, we say we know the quantity once we may assign the ratios with the said unity, assumed originally arbitrary. Now, even when we conceive forces in Lagrange's most general way, that is, as causes making quantities sometimes different from lines vary, the necessary data to be able to say that we know how to measure them occur: we have all that we reasonably are rightful to pretend: if it seems that the image by which we dress the concept up is missing, this is because we want to paint it like in the particular case of forces acting along straight lines: an unknown background remains, in these more general cases as well as in the most common one.

To strengthen this persuasion, let us make two considerations on the going of the Lagrangean method. In it one says: if $f, \varphi, \psi$, and so on are quantities that the force tend to vary, we must introduce in the mechanical general equation the terms $\lambda \delta f, \mu \delta \varphi, \nu \delta \psi$, and so on, and the coefficients $\lambda, \mu, \nu$, and so on will mean and measure those forces. We easily understand the plausibility of this assertion, since if we suppose that those forces were not present, those terms would not appear, that is, the $\lambda$, $\mu, \nu$, and so on would be zero: thus proved that such terms shall be present there, and in which way, we glimpse that those coefficients shall in some way encompass the expression of the forces (see also what we already said in the first part of $\mathrm{n}$. 56 p. m.). But the more suitable consideration to persuade us of this is that those coefficients $\lambda, \mu, \nu \ldots$ enter the general equation of Mechanics in a linear dimension: from which derives that we may have their multiples and half-multiples, once posed one of those forces arbitrarily as basis for the ratios.

Indeed, if we dealt with a force compelling a point of the body to lie on a surface with equation $L=0$, we know, independently on the principle discussed in this Memoir, that the term $\lambda \delta L$ enters the general equation, and that $\lambda$ is proportional to the pressure, which in that case is a force acting along a straight line. The $\lambda$, entering linearly, is doubled, tripled, and so on, or becomes the half, the third, and so one, if all the other terms of the equation are multiplied by 2,3 , and so on, or by $\frac{1}{2}$, $\frac{1}{3}$, and so on. Well: matters go the same way also when $\lambda$ is a factor introduced by virtue of the principle expounded in the A. M. in $\S 1{ }^{\text {st }}$, Sect. II. From here we may somehow explain what Lagrange meant, when in the said place he supported his new principle by saying that any quantity may be represented by a straight line: maybe he expressed himself in this way because the measure of forces is equally obtained so by adopting the wider sense we have said, as in the common acceptation of a force acting along a straight line. Moreover, our Author tried (art.5, Sez. IV) to reduce in any case the concept of force to that of pressures along straight lines perpendicular to surfaces: and to forces only acting linearly come our considerations on molecular actions expounded in Chapter VI p.m., and in Chapter III of the present Memoir. However, I do not give up considering wonderful and very useful the sights that our Author opened us by establishing the principle supported in this Memoir. Even if something remained to do to recognize which and how many should be the functions to adopt so to apply with certainty the above said principle: this does not detract the merit of having widened our ideas about forces.

Here it is appropriate to remark an analogy with the going one has for measuring some quantities relative to mathematical physics. For instance, called unity of heat the quantity of that cause, whatever it be, that produces a determined phenomenon, such as the fusion of a known amount of ice: we say double, triple, and so on, the quantity of heat producing the double, or triple, phenomenon, that is, the melting of a double, triple amount of ice. However, do we paint us an image of the way that unit of heat produces the unit phenomenon? I believe not: and, though we tried to do it, for sure it were not the shortening of a straight line. Similarly in our case the phenomenon collecting the effect of the force, instead of the above said, is the shrinking of an angle, the thickening of a density, and so on; the ignorance on the way of action of the cause does not affect the possibility to measure it. ${ }^{25}$

${ }^{25} \mathrm{Il}$ concetto che Lagrange voleva ci formassimo delle forze, e che esponemmo nel prologo, è più generale di quello universalmente ammesso. S'intende facilmente da tutti essere la forza una causa che mediante la sua azione altera la grandezza di certe quantità. Nel caso più ovvio, avvicinando un corpo o un punto materiale ad un altro, cambia distanze, ossia fa variare lunghezze di linee rette: ma può invece far variare un angolo, una densità, ec. In questi altri casi il modo di agire delle forze ci riesce oscuro, mentre ci par chiaro nel primo: ma forse la ragione di ciò è estrinseca alla natura delle forze. Per verità anche in quel primo caso non si capisce come faccia la forza a infondere la sua azione nel corpo sì da diminuirne od accrescerne la distanza da un altro corpo: nondimeno noi vediamo continuamente il fatto: l'osservazione giornaliera sopisce in noi la voglia di cercare più in là. Se però sottilmente esaminando si trova che qui pure il modo di agire delle forze è misterioso, nessuna meraviglia ch'esso ci appaja oscuro negli altri casi. Voler ridurre in ogni caso l'azione delle forze a quella che diminuisce una distanza, è impiccolire un concetto più vasto, è un non voler riconoscere che una classe particolare di forze. Generalmente parlando, a qual punto possono essere spinte le nostre cognizioni intorno alle cause che sottoponiamo a misura? forse a comprenderne l'intima natura, e il vero modo con cui agiscono? mainò. Scriveva Newton: Caveat lector ne per hujusmodi voces cogitet me speciem vel modum actionis causamve aut rationem physicam alicubi definire, vel centris (quœe sunt puncta mathematica) vires vere et physice tribuere, si forte aut centra trahere, aut vires centrorum esse dixero (Princ. Math. I., $1 .^{\circ}$, Def. VIII in fine). Radunato tutto quanto vi è d'incognito nelle unità di misura di una stessa specie, noi diciamo di conoscere la quantità, lorché possiamo assegnare i rapporti colla detta unità assunta originariamente arbitraria. Ora eziandio quando si concepiscono le forze alla maniera più generale di Lagrange, cioè siccome cause che fanno variare quantità talvolta diverse dalle linee, concorrono i dati necessari a poter dire che sappiamo misurarle: si ha tutto ciò che ragionevolmente ci è lecito di pretendere: se pare che ci manchi l'immagine con che rivestirne il concetto, è perché vogliamo colorirla come nel caso particolare delle forze che agiscono lungo le rette: un fondo incognito rimane sempre tanto in questi casi più generali, come in quello sì comune.

Per ajutare questa convinzione facciamo due considerazioni sull'andamento del metodo lagrangiano. In esso si dice: se $f, \varphi, \psi$, ec. sono quantità che le forze tendono a far variare, debbono introdursi nell'equazione generale meccanica i termini $\lambda \delta f, \mu \delta \varphi, \nu \delta \psi$, ec., e i coefficienti $\lambda$, $\mu, \nu$, ec. significheranno e misureranno quelle forze. Si capisce un cotal poco la ragionevolezza di questa asserzione, giacché supposto che quelle forze non vi fossero, quei termini non comparirebbero, ossia le $\lambda, \mu, \nu$, ec. sarebbero zero: provato adunque che essi termini debbano comparirvi, e a qual modo, s'intravede che quei coefficienti debbono in qualche maniera comprendere l'espressione delle forze (vedi anche il già detto nella prima parte del n. 56 m. p.). Ma la considerazione più atta a persuaderci di ciò è che tali coefficienti $\lambda, \mu, \nu \ldots$ entrano nella equazione generale della Meccanica in dimensione lineare: dal che deriva che possiamo averne i multipli e semimultipli, posta a base dei rapporti una di esse forze arbitrariamente.

Infatti, se si trattasse di una forza che obbliga un punto del corpo a stare sopra una superficie di equazione $L=0$, sappiamo indipendentemente dal principio discusso in questa Memoria, che nell'equazione generale entra il termine $\lambda \delta L$, e che $\lambda$ è proporzionale ala pressione, la quale in tal caso è una forza che agisce lungo una retta. La $\lambda$, entrando linearmente, si raddoppia, si triplica, ec., ovvero diventa la metà, il terzo, ec., se tutti gli altri termini dell'equazione sono moltiplicati per 2, 3, ec., ovvero per $\frac{1}{2}, \frac{1}{3}$, ec. Ebbene: la cosa procede allo stesso modo anche quando $\lambda$ è un fattore introdotto in forza del principio esposto nella M. A. al $\S 1 .^{\circ}$, Sez. II. Di qui può spiegarsi in qualche guisa quello che Lagrange ha voluto intendere, allorché nel luogo citato appoggiò il suo nuovo principio col dire che una quantità qualunque può essere rappresentata per una linea: forse così si espresse perché la misura delle forze si ottiene egualmente tanto adottando il senso 
It seems that we may find in this long passage the whole of Piola's path in continuum mechanics: physical phenomena should be mathematically characterized only via evident, undoubtable descriptions and quantities. For standard continua, described only via their geometry and configurations, the evident, undoubtable descriptions are purely geometrical, and reflect the possibility to refer the same shape with respect to two different frames. This view, dating back to 1850 , is absolutely modern: without disturbing relativity, most propositions in modern and contemporary physics descend from assumptions of invariance with respect to different observers. And, in addition, another powerful and still accepted view is that constitutive arguments should be kept separated from kinematical and balance considerations. Indeed, as Piola clearly and precisely remarked, the undoubtable variations of geometrical configurations happen independently of the nature of forces, of which we may have obscure ideas, and which are nothing more than a useful mathematical tool (Lagrangean multipliers).

The only postulate to be accepted is that the "most general mechanical equation" has Lagrange's form, that is, as we say nowadays, the balance of (virtual) power as a linear form written on the undoubtable descriptors of the configuration, seen by two different observers. If we accept this (and Piola never questioned this position - to him, Lagrange's balance of power is the actual, true mathematical translation of physical balance conditions), no matter how complicated the problem is, in principle we have the mathematical tools to obtain what we nowadays call its field equations. Indeed, as it is apparent from the second part of the passage quoted above, the key point of Piola's mechanics does not lie in the description of forces, but rather in catching the meaningful descriptors of the actual configuration of the considered body.

In a contemporary language, Piola stated that one shall catch the state descriptors of the body configurations; balance is, then, simply a matter of cranking the wheel of the well working Lagrange's variational machinery. Indeed, forces cannot simply be imagined as stretching a line (like the imaginary hands pulling ropes that one may see in 17th and 18th century books on mechanics, for instance in Varignon [55]): they are the most general actions dual to any change in the meaningful descriptors of the configuration of the body. Such an idea holds also for other physical phenomena: Piola calls for thermal processes as well, letting intend that there must be a way to imagine a variation of some function on which a Lagrangean multiplier, or better, a generalized force, spends power.

Thus, we may say that the whole of Piola's journey in continuum mechanics was following a path searching for a precise definition of those quantities characterizing the state of a continuum body. He, however, had clearly in mind he had found an answer, that was, in the case of purely geometrical processes (non-thermal), to adopt the variations of the quantities that we nowadays interpret as a Cauchy-Green strain tensor. While in his former papers Piola had neglected any interpretation for these "trinomials", in [38] he moved a step forward, because he said that

[...] I will show that, instead of those trinomials, we may assume quantities dressed up with a geometrical, sometimes even physical, representation. ${ }^{26}$

And, indeed, Piola proved, simply by suitable changes of coordinates and functions, that the three "trinomials" he had introduced as the condition equations to be used in Lagrange's balance of virtual power for the one-dimensional continua express the length of the arc element, the angle of contingence, and the angle of torsion of the curve. In this way, their variations naturally express, to a contemporary scholar in continuum mechanics, elongation, bending, and twist, respectively, and Piola called their mechanical duals tension, elasticity, and torsion, respectively, as it had been done by other mechanicians. For two-dimensional continua, he showed that the six "trinomials" he had introduced are expressions of the arc elements of two curves on the surface, of the plane angle between their tangents, of the radii of the osculating circles to these curves, and of the angle between these radii. The only difficulty Piola found was that at his time the theory of continuum surfaces was not so universally accepted, and there were no unique denominations for the mechanical duals of the variations of these measures (which nowadays we would call extension, plane shear, bending and twisting curvatures). For three-dimensional continua, somehow reflecting what one may read in [54], he showed that his "trinomials" express, as we accept also nowadays, strains. Indeed, he declared that, if the arc elements in the ideal state have, at a point $P$, tangent with director cosines $\alpha_{1}, \alpha_{2}, \alpha_{3}$, the square of the length of the arc element $s^{\prime}$ in the present configuration is given by:

$$
\left(s^{\prime}\right)^{2}=\sum_{i, j} C_{i j} \alpha_{i} \alpha_{j}, \quad \mathbf{C}=\mathbf{F}^{\top} \mathbf{F}
$$

più ampio di cui si è detto, quanto nell'accettazione comune di una forza che agisce lungo una linea. Del resto il nostro Autore si è provato (art. 5, Sez. IV) a ridurre in ogni caso il concetto di una forza a quello di pressioni lungo rette perpendicolari a superficie: e a sole forze agenti linearmente riescono anche le nostre considerazioni sulle azioni molecolari esposte nel Capo VI m.p., e nel Capo III della Memoria presente. Io però non cesso di reputare bellissime e assai utili le viste che il nostro Autore ci aperse collo stabilire il principio difeso in questa Memoria. Sia pure che restasse qualche cosa a fare per riconoscere quali e quante dovevano essere le funzioni da adoperarsi onde applicare con sicurezza il principio anzidetto: ciò nulla toglie al merito di aver allargate le nostre idee intorno alle forze.

E torna qui opportuno osservare un'analogia coll'andamento che si tiene per la misura di alcune quantità proprie della fisica matematica. Chiamata, per esempio, unità di calore la quantità di quella causa, qualunque essa sia, che produce un fenomeno determinato, qual è la fusione di una nota quantità di ghiaccio: diciamo doppia, tripla, ec., la quantità di calore che produce il fenomeno doppio, o triplo, cioè lo scioglimento di una doppia, tripla quantità di ghiaccio. Ma ci formiamo noi una immagine del modo col quale quella unità di calore produce il fenomeno unitario? Io credo di no: e quantunque tentassimo formarcela, certo non sarebbe l'accorciamento di una retta. Similmente nel caso nostro il fenomeno che raccoglie l'effetto della forza, invece del sopradetto, è il restringersi di un angolo, il costiparsi di una densità, ec.: l'ignoranza sul modo d'agire della causa non toglie il poterla misurare. [38], pp. 456-458.

${ }^{26}[\ldots]$ mostrerò che invece di que' trinomj si possono assumere quantità rivestite di una rappresentazione geometrica e qualche volta anche fisica. [38], p. 459. 
where the $C_{i j}$ are the components of $\mathbf{C}$ evaluated at $P$, and $\mathbf{F}$ collects the first derivatives of the transformation between the ideal and

the present configurations; the $C_{i i}$ coincide with the coefficients $\varepsilon$ that were called by Cauchy "la dilatation linéaire"27. Piola obtained also analogous expressions for the cosines of the angles between curves, and thus the interpretation of the mechanical duals of their variations is that of usual stress, that can be pulled back or pushed forward between the ideal and the present configurations. Piola provided also considerations on what we now would call the search of the principal axes of strain and stress, comparing his results with those by Cauchy in [54]; he also put into evidence that it is not evident, from kinematics and mechanics arguments only, that the principal axes of stress and strain coincide, thus revealing an acute outlook on one of the biggest questions of the 18th century theory of elasticity. In the rest of the memoir, Piola reconsidered molecular actions, introducing, as we would call them nowadays, some constitutive arguments, and some remarks on the difference between central molecular forces or "electrical fluid" forces.

\section{Piola's modernity and contributions}

The quotes from Piola's memoirs on mechanics show how far had he gone in his investigations, and how it is a pity that, due to a nationalistic spirit that kept him writing in Italian only in Italian journals, almost unknown to the international scientific community, his work has been almost forgotten until the diffusion of his name, mainly due to Truesdell's historic investigations on 18th and 19th century mechanics.

It is apparent, indeed, that Piola put into evidence some key ingredients for mechanics, accepted also nowadays. In my opinion, these are:

- a clear distinction between configuration (state) variables, balance, and constitutive arguments; only through a precise characterization of the state and its variations, indeed, can the Lagrangean machinery work; phenomenological specification of inner actions shall be produced separately because, in principle, they do not enter the variational apparatus. The state variables, or, better, the full description of the present configuration cannot be, apart from special cases, only geometrical: as Piola himself stated, forces tend to vary configuration descriptors that are not simply lengths but also angles, densities, 'electric fluid' quantity, and so on. Thus, the ground is ready for seeding multi-physical description, together with possible superposed structures that can help to describe the observed phenomena in a definite, undoubtable way. It seems that this position is one of the most advanced ones in mid-19th century;

- the introduction of a fictitious, yet mathematically powerful, ideal state, where particles are so regularly assembled that all physical quantities characterizing the configuration are represented by the simplest of functions (uniform, equal to unity or even vanishing). The idea of a natural state as a fictitious configuration that serves only as a useful term of comparison with the present shape did not belong to Lagrangean mechanics, to which Piola was inspired, and is an original mechanical tool. Many years later, it was Truesdell who introduced this idea again;

- a well working way of obtaining bulk and boundary balance by superposing a rigid body motion (or, equivalently, a change in observer) on the present configuration of the body: this view gets rid of difficult, if not sometimes impossible, imagines of forces pulling and pushing on small cubes, and was put into evidence for its originality by Hellinger [41] but soon forgotten because of Piola's provincialism; it seems that it was Truesdell, in his trip to Italy, to re-discover it and spread it again via his monographs;

- the idea that, since forces are simply Lagrangean multipliers of the variations condition equations (in the truth, Piola in his last work admitted that these equations actually represent generalized strains, or any sensible change in the physical sensible quantities characterizing the body configuration), it was immaterial to write bulk and boundary equations in the present or in the reference (ideal) configurations: while this was not so important in 19th century continuum mechanics, when scholars turned to investigate large displacements the importance of writing down equations in a known shape seemed apparent. A similar attempt by Kirchhoff in 1852 [56] was not precise and accurate as Piola's arguments and derivations.

It seems actually a pity that Piola's self-isolation, in the spirit of a nationalism and of a kind of amateurism that never accepted academic positions, let these positions be known very little outside a very small circle of pupils and followers. Indeed, it seems that even in Italy the school of rational mechanics soon followed the teaching of Betti, Beltrami and their schools, and forgot the amateur Piola. Maybe a good knowledge of the past may help in preparing the future.

Acknowledgements. This work has been partially supported by the grant "Progetti di ricerca d'Ateneo" by Sapienza University, Rome, Italy, for the year 2012.

${ }^{27}[54]$, p. 304. 


\section{References}

[1] Cauchy, AL. Recherches sur l'équilibre et le mouvement intérieur des corps solides ou fluides, élastiques ou non élastiques. Bulletin de la Societé Philomathique 1823, (3) 10: 9-13; Euvres (2) 2: 300-304.

[2] Cauchy, AL. De la pression ou tension dans un corps solide. Exercices de Mathématiques 1827, 2: 42-56; Euvres (2) 7: 60-78.

[3] Cauchy, AL. Sur la condensation et la dilatation des corps solides. Exercices de Mathématiques 1827, 2: 60-69; Euvres (2) 7: 82-93.

[4] Cauchy, AL. Sur les relations qui existent dans l'état d'équilibre d'un corps solide ou fluide, entre les pressions ou tensions et les forces accélératrices. Exercices de Mathématiques 1827, 2: 108-111; Euvres (2) 7: 141-145.

[5] Cauchy, AL. Sur les équations qui expriment les conditions d'équilibre ou les lois du mouvement intérieur d'un corps solide, élastique ou non élastique. Exercices de Mathématiques 1828, 3: 160-187; Euvres (2) 8: 195-226.

[6] Cauchy, AL. Sur l'équilibre et le mouvement d'un système de points matériels sollicités par des forces d'attraction ou de répulsion mutuelle. Exercices de Mathématiques 1828, 3: 188-213; Euvres (2) 8: 227-252.

[7] Cauchy, AL. De la pression ou tension dans un système de points matériels. Exercices de Mathèmatiques 1828, 3: 214-238; Euvres (2) 8: 254-277.

[8] Cauchy, AL. Sur l'équilibre et le mouvement intérieur des corps considérés comme des masses continues. Exercices de Mathèmatiques 1829, 4: 293-319; Euvres (2) 9: 243-369.

[9] Poisson, SD. Mémoire sur l'équilibre et le mouvement des corps élastiques (1828). Mémoires de l'Académie des Sciences de l'Institut de France 1829, (2) 8: $357-570$.

[10] Poisson, SD. Mémoire sur les équations générales de l'équilibre et du mouvement des corps solides élastiques et des fluides (1829). Journal de l'École Polytechnique 1831, 13: 1-174.

[11] Todhunter, I, and Pearson, K. A history of the theory of elasticity and of the strength of materials, from Galilei to the present time. Cambridge: The University Press, 1886.

[12] Dugas, R. Histoire de la mécanique. Neuchâtel: Griffon, 1950.

[13] Timoshenko, SP. History of strength of materials. New York: McGraw-Hill, 1953.

[14] Benvenuto, E. An introduction to the history of structural mechanics. New York: Springer, 1991.

[15] Capecchi, D, Ruta, G, and Tazzioli, R. Enrico Betti. Teoria della elasticità. Benevento: Hevelius, 2006.

[16] Capecchi, D, Ruta, G. La scienza delle costruzioni in Italia nell'Ottocento. Milano: Springer Italia, 2010.

[17] Capecchi, D, Ruta, G, and Trovalusci, P. From classical to Voigt's molecular models in elasticity, Archive for History of Exact Sciences 2010, 64: 525-559.

[18] Green, G. On the reflection and refraction of light at the common surface of two non-crystallized media (1839), in Mathematical papers, ed. Norman Macleod Ferrers, 245-269. London: MacMillan (1871).

[19] Thomson, W (Lord Kelvin). On the thermo-elastic and thermo-magnetic properties of matter (1855), Quarterly Journal of Mathematics 1857, 1: 57-77.

[20] Thomson, W (Lord Kelvin), and Tait, PG. Treatise on natural philosophy. Cambridge: The University Press, 1867.

[21] Truesdell, C, and Toupin, R. The classical field theories, in Handbuch der Physik III/1, ed. S. Flügge, 226-793. Berlin: Springer, 1960.

[22] Truesdell, C, and Noll, W. The non-linear field theories of mechanics, in Handbuch der Physik III/3, ed. S. Flügge, 226-793. Berlin: Springer, 1965.

[23] Gurtin, ME, Fried, E, and Anand, L. The mechanics and thermomechanics of continua. New York: Cambridge University Press, 2011.

[24] Cosserat E, and Cosserat F. Sur la théorie de l'élasticité, Annales de l'Université de Toulouse 1896, 10 : 1-116.

[25] Cosserat E, and Cosserat F. Sur la statique de la ligne déformable, Comptes rendus 1907, 145: 1409-1412.

[26] Capriz, G. Continua with microstructure. New York: Springer, 1989.

[27] Pignataro, M, Rizzi, N, Ruta, G, Varano, V. The effects of warping constraints on the buckling of thin-walled structures, Journal of Mechanics of Materials and Structures 2009, 4: 1711-1727.

[28] Brunetti, M, Paolone, A, Ruta, G. On inner shearing constraints for a direct beam model coarsely describing warping, Meccanica 2013, in press, DOI: $10.1007 / \mathrm{s} 11012-013-9759-\mathrm{y}$

[29] Alessi, R, Marigo, JJ, Vidoli, S. Variational approach to ductile fracture: a simple model with gradient-damage and plasticity, EUROMECH colloquium 548, Amboise, France, 24-26 June 2013.

[30] Pau, A, Trovalusci, P. Block masonry as equivalent micropolar continua: the role of relative rotations, Acta Mechanica 2012, 223 (7): $1455-1471$.

[31] Trovalusci, P, Pau, A. Derivation of microstructured continua from lattice systems via principle of virtual works. The case of masonry-like materials as micropolar, second gradient and classical continua, Acta Mechanica, in press. 
[32] Addessi, D, Sacco, E, Paolone, A. Cosserat model for periodic masonry deduced by nonlinear homogenization, European Journal of Mechanics - A/Solids 2010, 29(4): 724-737.

[33] Lippmann, H. Cosserat plasticity and plastic spin, Applied mechanics reviews 1995, 48: 753-762.

[34] Piola, G. Sull'applicazione de’ principi della meccanica analitica del Lagrange ai principali problemi. Milano: Regia Stamperia, 1825.

[35] Piola, G. La meccanica de' corpi naturalmente estesi trattata col calcolo delle variazioni, Opuscoli matematici e fisici di diversi autori 1833, 1: 201-236.

[36] Piola, G. Nuova analisi per tutte le questioni della meccanica molecolare Memorie di matematica e fisica della Società Italiana delle Scienze 1836, $21: 155-321$.

[37] Piola, G. Intorno alle equazioni fondamentali del movimento di corpi qualsivogliono considerati secondo la naturale loro forma e costituzione, Memorie di matematica e fisica della Società Italiana delle Scienze 1848, 24: 1-186. Translated in this volume.

[38] Piola, G. Di un principio controverso della Meccanica Analitica di Lagrange e delle sue molteplici applicazioni, Memorie dell'Istituto Lombardo 1856, 6: 389-496. Translated in this volume.

[39] Lagrange, JL. Mécanique Analytique. Paris: Courcier, 1811.

[40] Capecchi, D, Ruta, G. Piola's contribution to continuum mechanics, Archive for History of Exact Sciences 2007, 61 (4): 303-342.

[41] Hellinger, ED. Die allgemeine Ansätze der Mechanik der Kontinua, in Enzyklopädie der mathematischen Wissenschaften IV 30, ed. Felix Klein, 602-694. Leipzig: Teubner, 1914.

[42] Lamé, G. Leçons sur le théorie mathématique de l'élasticité des corps solides. Paris: Gauthier-Villars, 1866 (1st ed. Paris: Bachelier, 1852).

[43] Navier, CLMH. Résumé des leçons données a l'École des ponts et chaussées [...]. Troisième édition avec des notes et des appendices, par M. Barré de Saint-Venant. Paris: Dunod, 1864.

[44] Clebsch, RFA. Théorie de l'élasticité des corps solides, Traduite par MM. Barré de Saint-Venant et Flamant, avec des Notes étendues de M. Barré de Saint-Venant. Paris: Dunod, 1883.

[45] Capecchi, D, Ruta, G. A historical perspective of Menabrea's "principle of elasticity", Meccanica 2010, 45: 199-212.

[46] Capecchi, D, Ruta, G. Cerruti's treatment of linear elastic trusses, Meccanica 2011, 46: 1283-1298.

[47] dell'Isola, F, Andreaus, U, and Placidi, L. At the origins and in the vanguard of peri-dynamics, non-local and higher gradient continuum mechanics. An underestimated and still topical contribution of Gabrio Piola, Mechanics and Mathematics of Solids, to appear.

[48] Lanczos, C. The variational principles of mechanics. Toronto: University Press, 1970.

[49] Bravais, A. Études cristallographiques. Paris: Gauthier-Villars, 1866.

[50] Lacroix, SF. Traité du calcul différentiel et du calcul intégral, Paris: Bachelier, 1828.

[51] Bordoni, A. Lezioni di calcolo subime, Milano: Giusti, 1831.

[52] Bottazzini U. I matematici italiani e la 'moderna analisi' di Cauchy, Archimede 1989, 41: 15-29.

[53] Dahan Dalmedico A. Mathématisations. Augustin-Louis Cauchy et l’École française, Paris: Blanchard, 1994.

[54] Cauchy, AL. Mémoire sur les dilatations, les condensations et les rotations produites par un changement de forme dan uns système des points matériels. Exercices d'analyse et de physique mathématique 1841, 2: 302-330; Euvres (2) 12: 278-287.

[55] Varignon, P. Nouvelle mécanique ou statique, Paris: Claude Jombert, 1725.

[56] Kirchhoff, GR. Über die Gleichungen des Gleichgewichtes eines elastischen Körpers bei nicht unendlich kleinen Verscheibungen seiner Theile, Sitzungsberichte der Akademie der Wissenschaften Wien 1852, 9: 762-773. 